\title{
The effects of land use types and soil depth on soil properties of Agedit watershed, Northwest Ethiopia
}

\author{
Eyayu Molla Fetene ${ }^{1 *}$ and Mamo Yalew Amera ${ }^{2}$ \\ $1 *$ Department of Natural Resource Management, College of Agriculture and Environmental Sciences, \\ Bahir Dar University, P.O. Box 79, Bahir Dar, Ethiopia \\ ${ }^{2}$ Amhara Region Water, Irrigation and Energy Bureau, P. O. Box 88, Bahir Dar, Ethiopia
}

\begin{abstract}
Assessing the impacts of different land uses on soil physicochemical properties is a fundamental step towards sustainable land management. This study was conducted in Agedit watershed, northwest Ethiopia with the objective of determining the effects of land use and soil depth on soil physicochemical properties. Three major land use types: natural forest, grazing and cultivated lands were selected while soil samples were collected in the 0-20 and $20-40 \mathrm{~cm}$ depths. Standard soil analytical procedures were followed in carrying out soil analysis. Statistical analysis revealed notable variations due to differences in land use type and soil depth. Sand and clay particles, bulk density, total porosity, $\mathrm{pH}$, organic matter, total nitrogen, available phosphorus, cation exchange capacity and exchangeable $\mathrm{K}$ and $\mathrm{Na}$ were significantly affected ( $\mathrm{p} \leq 0.05$ and/or $\mathrm{p} \leq 0.01)$ by land use. In contrast, silt, particle density, carbon to nitrogen ratios, exchangeable $\mathrm{Ca}$, and $\mathrm{Mg}$ and PBS were not significantly ( $\mathrm{p}>0.05$ ) affected. With soil depth, higher mean values of total nitrogen, organic matter, exchangeable $\mathrm{K}$ and $\mathrm{pH}$ were recorded in the $0-20 \mathrm{~cm}$ than in the $20-40 \mathrm{~cm}$ depth. A shift from forest to other land use types caused a significant decline on soil fertility parameters which contributed to low agricultural productivity. The study area, therefore, needs immediate intervention to protect the remnant forests and to replenish the degraded soil properties for sustainable agricultural productivity.
\end{abstract}

Key words: cultivation, deforestation, grazing, land management, soil fertility

DOI: http://dx.doi.org/10.4314/ejst.v11i1.4

\section{INTRODUCTION}

Land degradation resulting from land use change has been a major global challenge since the $20^{\text {th }}$ century and will remain high on the international agenda in the $21^{\text {st }}$ century (Eswaran et al., 2001). Particularly, deforestation and the subsequent conversion of the land into different land uses such as cropland and grazing areas caused significant changes to soil properties in many parts of the tropical regions (Islam and Weil, 2000; Rao and Pant, 2001; Adolfo-Campos et al., 2007). The amount, rate and intensity of land use changes are mainly considerable in developing countries (Rao and Pant, 2001).The outcomes of these changes are deterioration of soil physicochemical properties, increased soil erosion or soil compaction (Rao and Pant, 2001) and land degradation (Woldeamlak Bewket and Stroosnijder, 2003; Khresat et al., 2008). As a result, cultivated soils in different parts of the tropics are now below their potential levels.

Ethiopia is endowed with potentially rich natural resources, of which land is the principal one and

\footnotetext{
*Corresponding author: eyayuelza@yahoo.com

(C) This is an Open Access article distributed under the terms of the Creative Commons Attribution License (http://creativecommons.org/licenses/CC BY4.0).
} 
agriculture is the foundation for the economy of the country. The agriculture sector plays a central role in the life and livelihood of most Ethiopians, where about 12 million smallholder farming households account for an estimated $95 \%$ of agricultural production. Thus, the sector provides $85 \%$ of all employment and contributes $44 \%$ to the country's gross domestic product (GDP) and $85 \%$ of the country's export earnings (UNDP, 2014). However, land productivity is continuously declining due to deforestation, continuous cultivation and inadequate land management practices.

Changes in land use, mainly the conversion of natural forests to agricultural land and settlement, are the most widely practiced activities in Ethiopia (Eyayu Molla et al., 2010). Such changes and the continuous use of land for cultivation and grazing purposes for centuries resulted in disastrous loss of soil nutrients, particularly in the highlands where erosion is more severe (Betru Nedassa, 2003; Eyayu Molla et al., 2010). As a result, agricultural activities in the country have increasingly expanded from gentle slopping surfaces in the highlands to steeply sloped areas of the nearby hills and mountain surfaces (Betru Nedassa, 2003). In addition to improper land use systems, the traditional farming practices that have been carried out for centuries, inadequate or inappropriate soil and water conservation measures and continuous clearing of forests for cultivation purposes have worsened soil degradation (Eyayu Molla et al., 2010).

Despite the general understanding of the impacts of land use change as hazards to agricultural productivity, very few studies have been done to quantify the extent, rate and process of soil fertility depletion under different land use and management practices in Ethiopia (Eyasu Elias, 2002). Among the very few, the study of Dawit Solomon et al., (2002) indicated a significant decline in soil organic carbon (OC) after conversion of a humid tropical forest to maize (Zea mays) cultivation in southwestern Ethiopia. Similar studies also reported a decline in soil organic carbon and total nitrogen stocks in cultivated soils compared to in soils of natural vegetation in southern Ethiopia (Mulugeta Lemenih and Fisseha Itanna, 2004), southeastern Ethiopia (Fantaw Yimer et al., 2007) and in the Blue Nile Basin, northwest Ethiopia (Woldeamlak Bewket and Stroosnijder, 2003). A study by Dawit Solomon et al., (2002a) also reported a decline in the amount of total phosphorus following clear cutting and long term cultivation and establishment of plantation forest in the sub-humid tropical environment of southwest Ethiopian highlands. Similar studies in different parts of the world also reported that the conversion of forests to different land uses affected soil physicochemical properties through its effect on soil organic matter and different nutrients (Islam and Weil, 2000; Chen and Li, 2003; Khresat et al., 2008). The associations of soil properties also vary with soil depth. So far, very few quantitative studies have been done to assess the effects of soil depth on soil properties in Ethiopia. Of these, studies by (Fantaw Yimer et al., 2007; Eyayu Molla et al., 2009) have reported variations in soil parameters with soil depth under different land uses in southeastern and northwest Ethiopia, respectively. These studies support the idea that soil properties react to depths across the various land use types.

Even if the impacts of improper land use changes are well understood, the magnitude of these effects on soil properties have not been scientifically studied and documented in the northwest highlands of Ethiopia. Therefore, 
evaluating land use induced changes and soil depth on soil properties in different parts of the region is essential for understanding the impacts of agro-ecosystem transformation on soil productivity and to come up with appropriate and sustainable soil and land management options. As assessment of soil quality involves measuring of physical and chemical properties of a soil under different land use scenarios with soil depth, such kinds of studies will help to better understand the relative dynamics of soil properties to changes in land use/cover in the northwestern highlands of Ethiopia and other similar environments in the country. On top of this, no quantitative evidence has been reported on the extent of soil properties variation associated with land use types and soil depth in the study area. Therefore, this study was initiated to assess the impacts of different land use systems and soil depth on selected soil physicochemical properties in Agedit watershed, northwest Ethiopia.

\section{MATERIALS AND METHODS}

\section{Location of the study site}

Agedit watershed is located in Farta District, South Gondar Zone of the Amhara National Regional State (ANRS), northwestern Ethiopia. It is situated $684 \mathrm{~km}$ northwest of Addis Ababa and $18 \mathrm{~km}$ northeast of Debre Tabor town (Figure 1). Geographically, the study site lies at $11^{0} 43.8^{\prime}$ to $11^{\circ} 45^{\prime}$ latitude and $38^{\circ} 08^{\prime}$ to $38^{\circ} 10^{\prime}$ E longitude and at an altitude ranging from 2793 to 2864 meters above sea level (masl). It covers an area of about 313.36 ha located south of mount Guna. The area is characterized by gently undulating to undulating plain with slope ranges of 5 to $25 \%$. Such topographical setting makes it a source of many streams and small rivers that drain to the Rib River, which is part of the Lake Tana basin.

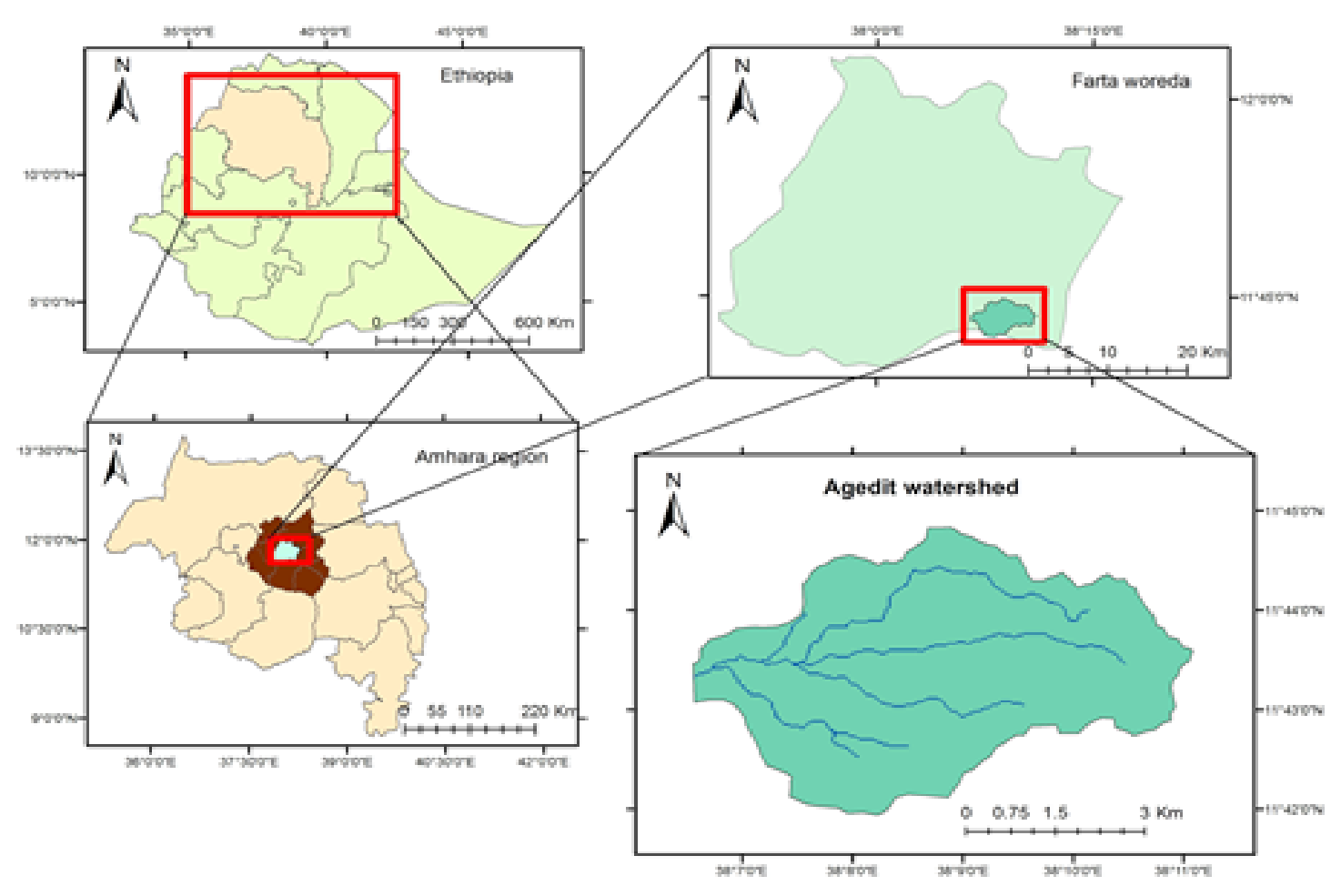

Figure 1. Location map of the study area 
Following the Ethiopian traditional agro-climatic zonation, the study area falls in the Moist Dega climatic (sub-humid) zone. A ten year (2004-2014) climatic data from a nearby meteorological center (Debere Tabor 2706 masl, $11^{\circ} 51^{`} \mathrm{~N}$ and $38^{\circ} 1^{`} \mathrm{E}$ ) recorded an average annual precipitation of 1444.5 $\mathrm{mm}$ with more than $80 \%$ of the rain occurring between June and September, and the mean annual temperature is $15.8{ }^{\circ} \mathrm{C}$ with a mean minimum of $9.3^{\circ} \mathrm{C}$ and mean maximum of $22.3^{\circ} \mathrm{C}$ (Figure 2).

Geologically the study area is covered with thick trap series volcanic rocks which erupted from fissures during the early and middle tertiary and from choke shield volcanic mountain center during the Miocene and Pliocene. The trap volcanic series consists mainly of weathered and jointed basalt (Mohr, 1971).

The majority of the soils in Farta district in general and the study area in particular are chromic
Luvisols that are silt loam in texture and reddish brown to dark brown in color (FAO, 1984). The soils of the Agedit watershed and of the district in general have been continuously cultivated and are thus nutritionally depleted.

\section{Land Use and Farming System}

The major land use patterns in the study watershed are indicated in Figure 3. The cultivated land accounts for $45.9 \%$, grazing land $25.8 \%$, forest lands $7.4 \%$ and the remaining $20.9 \% \%$ of the total area coverage is used for settlement. Some of the existing remnant forests are mainly confined to the mountain ridges and steep slopes, around the monasteries, churches and burial grounds. The dominant tree species of the natural forest are Olea europaea L. subsp cuspidata, Cordia africana Lam., Acacia abyssinica Hochst., Croton macrostachyus Del., and Hajenia abyssinica, There is a considerable tract of exotic tree

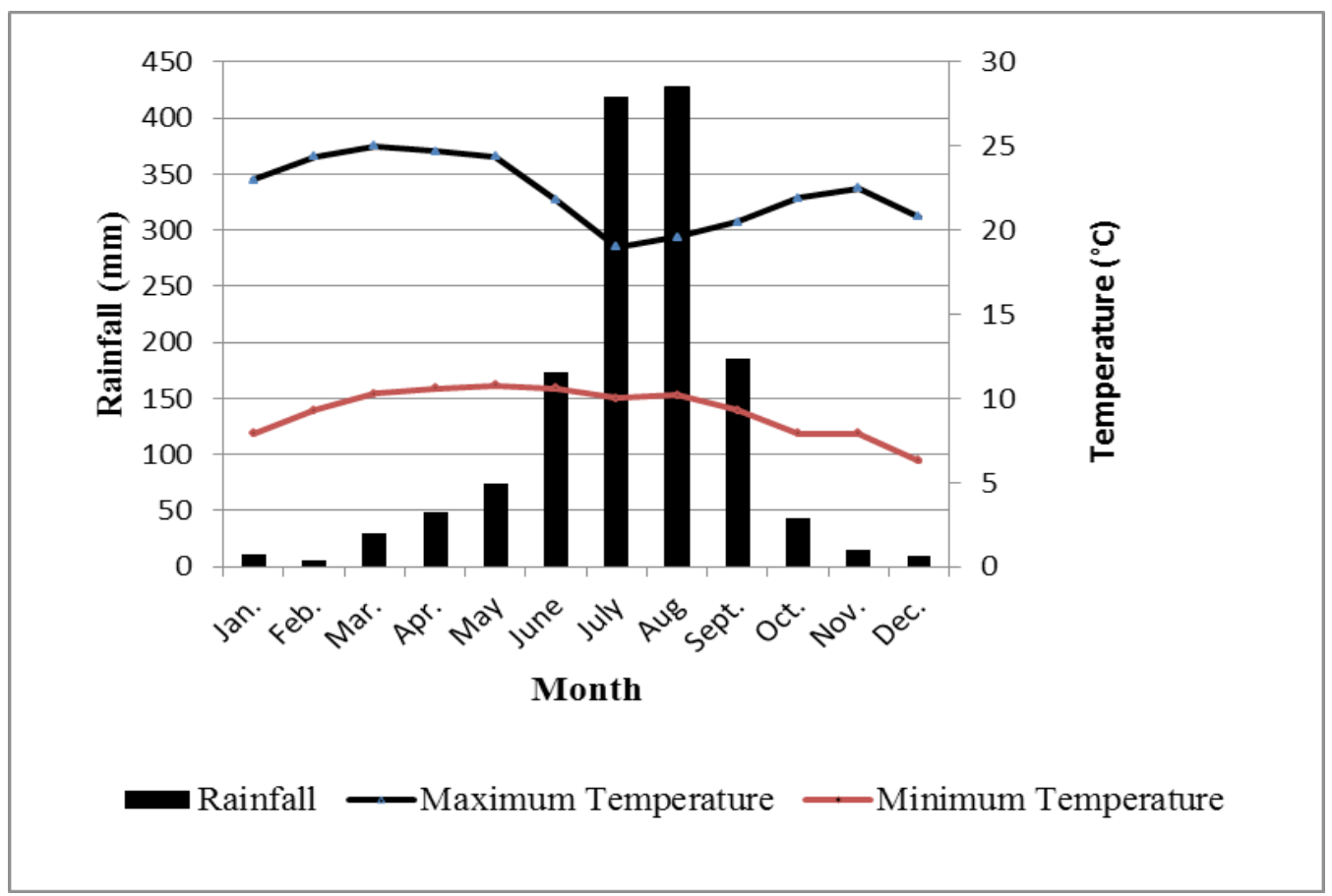

Figure 2. Mean monthly rainfall $(\mathrm{RF})$, maximum and minimum temperatures $\left({ }^{\circ} \mathrm{C}\right)$ of the study area (2004-2014), Northwestern Ethiopia. (Data from Ethiopian National Meteorological Service Agency, 2015). 
plantations dominated by species of Eucalyptus globulus, Cupressus lusitanica, Pinus patula, and Grevillea robusta grown around homesteads and as plantation forests. The watershed land use is dominated by traditional rain feed subsistence farming and grazing on communal lands (Figure 3).

Subsistence farming of mixed crop-livestock with barely (Hordeum vulgare), wheat (Triticum aestivum) horse beans (Vicia faba), peas (Pisum sativum), potato (Solanum tubersoum,), teff (Eragrostis tef), and maize (Zea mays) crops grown under rain fed conditions are the means of livelihood of the farming community. Cattle and small ruminants comprise the major livestock classes raised by the community in the watershed.

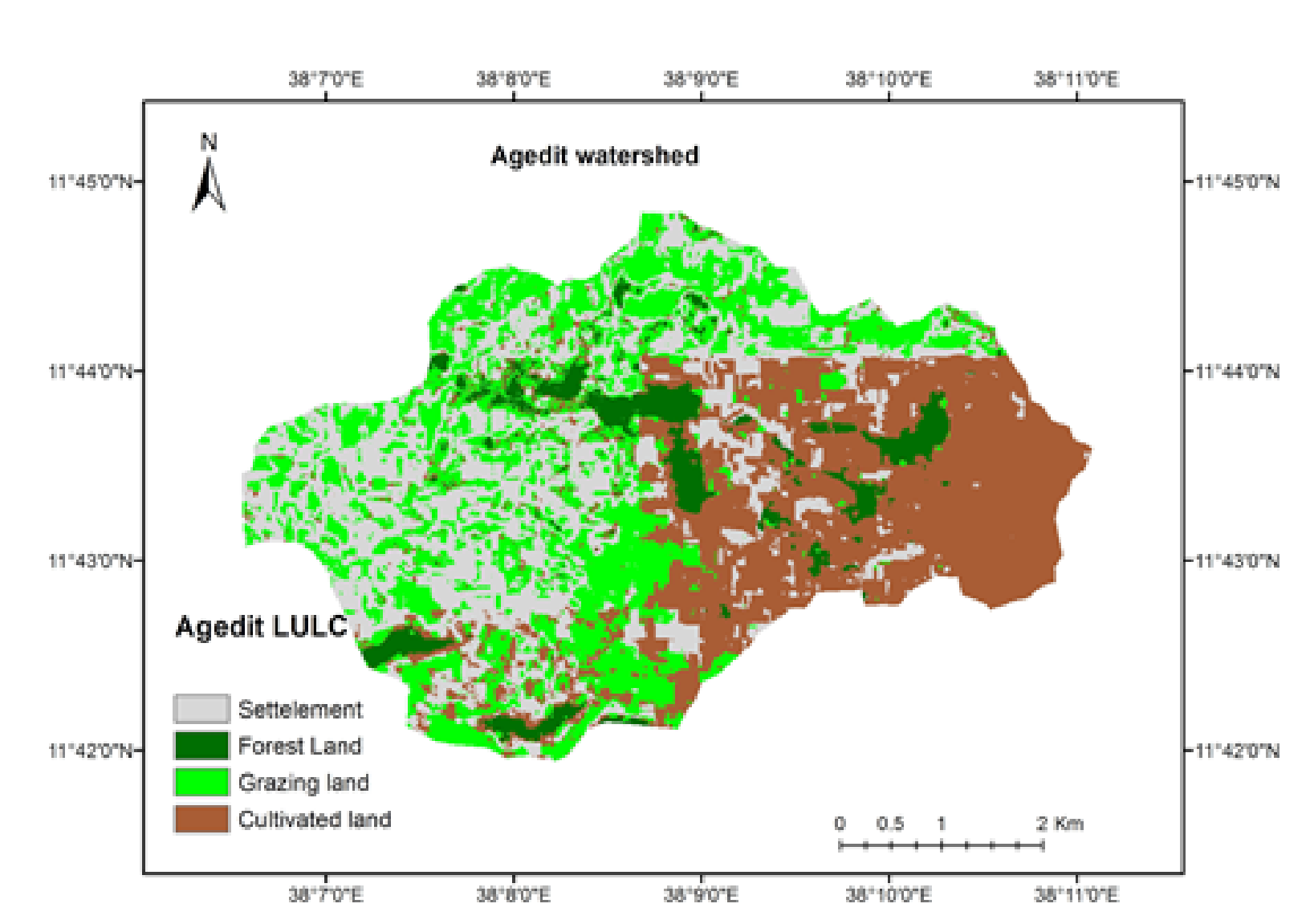

Figure 3. Land use/cover map of Agedit watershed

\section{Soil sampling and laboratory analysis}

\section{Soil sampling}

After a reconnaissance survey, three major land use types (natural forest, grazing land and cultivated lands) were selected in the watershed. Information on previous land use history was documented from oral histories communicated by local elder farmers who were the owners of the lands. Soil samples were collected from representative sites of each of the three land use types in four replicates. Precautions were taken during the selection of sampling sites to locate them within similar physiographic conditions such as slope and aspect. Four representative plots $(20 \mathrm{~m} \times 20 \mathrm{~m})$ for 
each land use types were located adjacent to and to a maximum distance of 200 to $250 \mathrm{~m}$ from the natural forest and within the natural forest. Before sampling, plant and grass litter including any other material on the soil surface were removed. Then, in each plot soil, samples were collected in four corners and at center in two different soil depths i.e $0-20 \mathrm{~cm}$ and $20-40 \mathrm{~cm}$. Each of the soil samples from the two depths consisted of five sub-samples that were bulked to make a single composite soil sample for the respective soil depths. Consequently, a total of 24 composite samples were collected from the three land use types (3 land uses x 2 depths x 4 replications). Additional undisturbed soil core samples of known volume were collected in all plots of each land use type and sample depths in four replications for bulk density determination.

\section{Laboratory analysis}

The disturbed composite soil samples collected from the representative plots of each land use type were air-dried, mixed well and passed through a 2 $\mathrm{mm}$ sieve for the analysis of selected soil physical and chemical properties. The soil physical and chemical analysis was carried out in soil testing laboratory in Gondar and in the national soil testing laboratory, Addis Ababa. Standard laboratory procedures were followed in the analysis of selected physicochemical properties considered in the study.

Soil bulk density $(\mathrm{Db})$ was determined after the soil was oven dried at $105{ }^{\circ} \mathrm{C}$ for $24 \mathrm{hr}$ (Blake, 1965) and particle density (Dp) was determined by the pycnometer method. Particle size distribution was analyzed by the Bouyoucos hydrometer method (Day, 1965). Soil $\mathrm{pH}$ was measured using a $\mathrm{pH}$ meter in a 1:2.5 soil: water ratio suspension. Soil organic carbon was determined following the wet digestion method (Walkley and Black, 1934) and soil organic matter (SOM) was calculated by multiplying percent of organic carbon by a factor of 1.724. Total nitrogen was determined using the micro-Kjeldahl digestion, distillation and titration procedure (Bremner and Mulvaney, 1982). Available phosphorus was measured following the Olsen method (Olsen et al., 1954). Cation exchange capacity (CEC) and exchangeable bases $(\mathrm{Ca}, \mathrm{Mg}, \mathrm{K}$ and $\mathrm{Na}$ ) were determined after extracting the soil samples by ammonium acetate $\left(1 \mathrm{~N} \mathrm{NH}_{4} \mathrm{OAc}\right)$ at $\mathrm{pH}$ 7.0. Exchangeable $\mathrm{Ca}$ and $\mathrm{Mg}$ in the extract was analyzed using atomic absorption spectrophotometer, while $\mathrm{Na}$ and $\mathrm{K}$ were analyzed by flame photometer (Chapman, 1965). Cation exchange capacity was thereafter estimated titrimetrically by distillation of ammonium that was displaced by sodium from $\mathrm{NaCl}$ solution (Chapman, 1965). Percentage base saturation (PBS) was calculated as the ratio of the sum of the charge equivalents of the base-forming cations ( $\mathrm{Ca}, \mathrm{Mg}, \mathrm{Na}$ and $\mathrm{K}$ ) to the $\mathrm{CEC}$ of the soil. Total pore space was computed from the values of bulk density (BD) and particle density (PD) as:

Percentage of Total porosity $(\mathrm{f})=\{1-\mathrm{Db} / \mathrm{Dp}\} * 100$, where $\mathrm{Db}=$ bulk density and $\mathrm{Dp}=$ particle density.

\section{Statistical analysis}

Prior to statistical analysis, treatments were arranged in factorial randomized complete block design format with land use and soil depth as factors. Then, statistical differences between the values for the various parameters of land use type and soil depth were tested using a two-way analysis of variance (ANOVA) following the General Linear Model (GLM) procedure of Statistical Analysis System (SAS) version 9.00 (SAS, 2002). When 
significant differences were observed comparisons of means were performed using Tukey's Honest Significant Difference (HSD) at 5\% probability level. Pearson's correlation coefficient was computed to examine the relationship between different soil properties.

\section{RESULTS AND DISCUSSION}

\section{Soil texture}

Textural analysis showed a significant difference in clay and sand fractions in both land use type $(p<0.01)$ and soil depth $(p<0.05)$ while there were no differences due to interaction effect (Table 1). Significantly higher sand was recorded in cultivated land and clay in forest and grazing lands. Nevertheless, no significant difference ( $p$ $>0.05$ ) was observed in the silt fraction among land use type and soil depth (Table 2). The higher sand and lower clay fraction in cultivated land most likely arise from disturbance during plowing and selective removal of clay particles by erosion leaving behind the sand fractions in site. The absence of vegetation cover could also cause the decline of organic matter which in turn affects the soil aggregates to be disaggregated and consequently the finer particles (such as clay) to be washed out via erosion (Abbasi et al., 2007). The increase in clay content and a decrease in the sand and silt fractions in the lower soil layers could be attributed to the downward migration of clay particles in the soil profile as evidenced

Table 1. Mean square estimates for a two-way analysis of variance of soil properties under three land use types and two soil depths

\begin{tabular}{|c|c|c|c|c|c|}
\hline \multirow[b]{2}{*}{ Soil parameter } & \multicolumn{5}{|c|}{ Mean squares for source of variation ${ }^{\dagger}$} \\
\hline & Land use (2) & Depth (1) & Land use x Depth (2) & Error (10) & $\mathrm{CV}(\%)$ \\
\hline Sand & $249.55^{* *}$ & $88.88^{*}$ & $20.22^{\mathrm{ns}}$ & 14.88 & 13.49 \\
\hline Silt & $176.88^{\mathrm{ns}}$ & $186.88^{\mathrm{ns}}$ & $32.88^{\mathrm{ns}}$ & 62.88 & 25.90 \\
\hline Clay & $432.88^{* *}$ & $512.00^{*}$ & $8.0^{\text {ns }}$ & 39.42 & 15.35 \\
\hline Bulk density & $0.27^{* *}$ & $0.028^{\mathrm{ns}}$ & $0.017^{\mathrm{ns}}$ & 0.018 & 10.79 \\
\hline Particle density & $0.04^{\mathrm{ns}}$ & $0.001^{\mathrm{ns}}$ & $0.0038^{\mathrm{ns}}$ & 0.010 & 4.08 \\
\hline Total porosity & $460.65^{* *}$ & $59.29^{\mathrm{ns}}$ & $16.82^{\mathrm{ns}}$ & 30.67 & 11.26 \\
\hline $\mathrm{pH}\left(\mathrm{H}_{2} \mathrm{O}\right)$ & $0.76^{* *}$ & $0.35^{*}$ & $0.087^{\mathrm{ns}}$ & 0.068 & 4.77 \\
\hline Soil OM & $2.18^{* *}$ & $3.68^{* *}$ & $1.045^{\mathrm{ns}}$ & 0.348 & 22.26 \\
\hline Total Nitrogen & $0.03^{* *}$ & $0.013^{* *}$ & $0.0007^{\mathrm{ns}}$ & 0.002 & 19.74 \\
\hline $\mathrm{C}: \mathrm{N}$ ratio & $4.89^{\mathrm{ns}}$ & $0.97^{\mathrm{ns}}$ & $0.74^{\mathrm{ns}}$ & 3.68 & 29.36 \\
\hline Available P & $4.15^{*}$ & $0.09^{\text {ns }}$ & $0.73^{\mathrm{ns}}$ & 0.77 & 23.95 \\
\hline Exchangeable $\mathrm{Ca}$ & $26.86^{\mathrm{ns}}$ & $4.08^{\mathrm{ns}}$ & $2.33^{\mathrm{ns}}$ & 10.81 & 24.64 \\
\hline Exchangeable $\mathrm{Mg}$ & $0.70^{\mathrm{ns}}$ & $0.81^{\mathrm{ns}}$ & $2.16^{\mathrm{ns}}$ & 0.607 & 23.59 \\
\hline Exchangeable K & $1.14^{* *}$ & $0.016^{\mathrm{ns}}$ & $0.02^{\mathrm{ns}}$ & 0.034 & 25.41 \\
\hline Exchangeable $\mathrm{Na}$ & $0.002^{*}$ & $0.006^{*}$ & $0.002^{\mathrm{ns}}$ & 0.0008 & 23.76 \\
\hline $\mathrm{CEC}$ & $5.10^{* *}$ & $6.58^{* *}$ & $10.04^{\mathrm{ns}}$ & 0.64 & 3.58 \\
\hline PBS & $575.36^{\mathrm{ns}}$ & $10.07^{\mathrm{ns}}$ & $73.47^{\mathrm{ns}}$ & 280.76 & 21.36 \\
\hline
\end{tabular}

"Figures in parenthesis $=$ Degrees of freedom; * = Significant at $\mathrm{p}=0.05 ; * *=$ Significant at $\mathrm{p}=0.01$; $\mathrm{ns}=$ Non-significant; $\mathrm{C}: \mathrm{N}=$ carbon nitrogen ratio; $\mathrm{CEC}=$ Cation Exchange Capacity $; \mathrm{PBS}=$ Percentage base saturation 
by its higher contents in the $20-40 \mathrm{~cm}$ depth and the selective removal of finer soil particles from surface soils by erosion leaving behind the coarser (sand and silt) fractions. This result goes well with similar studies by Woldeamlak Beweket and Stroosnijder (2003), Wakene Negassa and Heluf Geberekidan (2003) and Eyayu Molla et al., (2009) who found higher clay content in lower soil depths and forest land than the cultivated and grazing lands. The resemblance of this result to the works of these authors could be associated with the similarity in ecosystem and land management practices.

\section{Bulk density (BD) and Porosity}

Soil BD was significantly $(\mathrm{p}<0.01)$ affected by land use, but not $(\mathrm{p}>0.05)$ with soil depth and the interaction effect of both factors (Table 1). Soils under grazing land followed by cultivated land had the higher BD values than the adjacent soils of natural forest (Table 2). Thus relative to the natural forest, $\mathrm{BD}$ in cultivated and grazing lands increased by 27.50 and $40.20 \%$, respectively. This is comparable with the results of Celik, (2005) and Eyayu Molla et al., (2009) that reported an increase in BD in different land use types as compared to forest land. Similarly, the overall mean BD with soil depth increased numerically with an increase of depth, but without significant difference ( $p>$ 0.05 ) due to overlying weight and a decline in soil organic matter (SOM) as depth increases.

These differences are possibly related to variations of SOM since the observed correlation $\left(r^{2}=-0.82\right.$, $\mathrm{p}<0.01)$ indicated that changes in BD values are ascribed to changes in SOM content. Agricultural practices such as plowing and harvesting of crop residue, tampering by the hoof of animals and over grazing increased exposure of soil to direct temperature and precipitation both in grazing and cultivated lands, and these could be factors for the

Table 2. Main effects of land use and soil depth on selected soil physical properties

\begin{tabular}{|c|c|c|c|c|c|c|c|}
\hline \multirow{2}{*}{$\begin{array}{l}\text { Land use or } \\
\text { Soil depth }\end{array}$} & \multicolumn{3}{|c|}{ Particle size $(\%)$} & \multirow{2}{*}{$\begin{array}{l}\text { Textural } \\
\text { class }\end{array}$} & \multirow{2}{*}{$\begin{array}{l}\mathrm{BD}^{* *} \\
\left(\mathrm{~g} \mathrm{~cm}^{-3}\right)\end{array}$} & \multirow{2}{*}{$\begin{array}{l}\text { PD } \\
\left(\mathrm{g} \mathrm{cm}^{-3}\right)\end{array}$} & \multirow{2}{*}{$\begin{array}{l}\mathrm{TP} \\
(\%)\end{array}$} \\
\hline & Sand & Silt & Clay & & & & \\
\hline \multicolumn{8}{|l|}{ Land use type } \\
\hline Forest & $* * 29.16 b$ & 28.17 & $* * 42.67 \mathrm{a}$ & $\mathrm{C}$ & $* * 1.02 \mathrm{~b}$ & 2.53 & $* * 59.09 a$ \\
\hline Grazing & $* * 29.49 b$ & 29.18 & $* * 41.33 \mathrm{a}$ & $\mathrm{C}$ & $* * 1.43 \mathrm{a}$ & 2.51 & $* * 45.53 \mathrm{~b}$ \\
\hline Cultivated & $* * 33.16 \mathrm{a}$ & 30.17 & $* * 36.67 b$ & $\mathrm{CL}$ & $* 1.30 \mathrm{a}$ & 2.38 & $* * 42.84 \mathrm{~b}$ \\
\hline $\operatorname{LSD}(0.05)$ & 4.94 & NS & 8.08 & - & 0.173 & NS & 7.12 \\
\hline $\operatorname{SEM}( \pm)$ & 1.57 & 3.24 & 2.56 & - & 0.055 & 0.413 & 2.26 \\
\hline \multicolumn{8}{|l|}{ Soil depth (cm) } \\
\hline $0-20$ & $* 30.83^{\mathrm{a}}$ & 33.84 & $* 35.56^{\mathrm{b}}$ & $\mathrm{CL}$ & 1.21 & 2.50 & 50.96 \\
\hline $20-40$ & $* 26.38^{\mathrm{b}}$ & 27.40 & $* 46.22^{\mathrm{a}}$ & $\mathrm{C}$ & 1.29 & 2.45 & 47.34 \\
\hline $\operatorname{LSD}(0.05)$ & 4.05 & NS & 6.59 & - & NS & $\mathrm{NS}$ & NS \\
\hline $\operatorname{SEM}( \pm)$ & 1.28 & 2.64 & 2.09 & - & 0.045 & 0.033 & 1.85 \\
\hline CV $(\%)$ & 13.49 & 25.90 & 15.35 & - & 10.79 & 4.08 & 11.26 \\
\hline
\end{tabular}

Mean values within a column followed by the different letters are significantly different from each other at $* * \mathrm{p}<0.01$ and $* \mathrm{p}<0.05$; (NS = Not significant; $\mathrm{BD}=$ Bulk density; $\mathrm{PD}=$ Particle density $\mathrm{TP}=$ Total porosity; $\mathrm{C}=$ clay; $\mathrm{CL}=$ clay loam) 
variation of $\mathrm{BD}$ values among land use type and soil depth (Islam and Weil, 2000; Woldeamlak Bewket and Stroosnijder, 2003; Khresat et al., 2008; Eyayu Molla et al., 2009). Similarly total porosity showed a similar trend with bulk density (Table 1). It was significantly $(\mathrm{p}<0.05)$ affected by land use but showed insignificant $(p>0.05)$ difference with soil depth and by the interaction effects of both factors (Table 2). This is expected as porosity is negatively correlated $\left(r^{2}=-0.90, \mathrm{p}<\right.$ 0.01 ) and affected by BD. In contrast, statistically insignificant but numerically higher particle density values recorded in forest land and in the $0-20 \mathrm{~m}$ soil depth (Table 2) that might be associated to the presence of some heavy minerals as reported in the studies of Wakene Negassa and Heluf Gebrekidan (2003).

\section{Soil reaction $(\mathrm{pH})$}

The soil $\mathrm{pH}$ value was significantly affected by land use $(\mathrm{p}<0.01)$ and soil depth $(\mathrm{p}<0.05)$ while their interactions had no effect $(\mathrm{p}>0.05)$ (Table 1). Considering the effects of land use, the highest (5.86) and the lowest (5.20) soil $\mathrm{pH}$ values were recorded under the forest and the cultivated lands, respectively (Table 3). Thus, soils under the grazing and cultivated lands were found to be more acidic by 0.55 and 0.66 units, respectively. The relatively low mean value of soil $\mathrm{pH}$ under the grazing land and cultivated land might be due to depletion and removal of basic cations as a result of continuous soil disturbance and hence soil erosion. Loss of base forming cations down the soil profiles through leaching, depletion of basic cations due to crop residue harvest and continuous use of ammonium based fertilizers such as diammonium phosphate $\left(\left(\mathrm{NH}_{4}\right)_{2} \mathrm{HPO}_{4}\right)$ in the cereal based cultivated fields could contribute to increased acidity level. Similarly, the higher mean $\mathrm{pH}$ value
(5.60) was detected in the $20-40 \mathrm{~cm}$ depth (Table $3)$. The reason could be an increase in basic cation along soil depth which increases soil $\mathrm{pH}$ from top to down the soil profile as $\mathrm{pH}$ and basic cations usually show strong and positive relationship with each other. The result concurs with studies by (Amare Haileslassie et al., 2005; Eyayu Molla et al., 2009) who reported lower $\mathrm{pH}$ values under cultivated and grazing lands than forest land in central and northwest Ethiopia, respectively. On the other hand, an increase in soil $\mathrm{pH}$ along the soil depth indicates accumulation of bases (Kumar et al., 2012). Generally, the soil $\mathrm{pH}$ of the study area ranges from 5.20 to 5.80 and was rated as "strongly acidic" to "moderately acidic" as per the soil pH classification by Tekalign Tadesse (1991).

\section{Soil organic matter (SOM) and total nitrogen (TN)}

SOM and TN contents were significantly $(p<0.01)$ affected by land use and soil depth, but they showed insignificant values by the interaction effect of land use and soil depth ( $p>0.05$; Table 1). The mean values of both SOM and TN were higher in the natural forest but lower in the cultivated land. However, there was no statistically significant difference between the SOM contents of the forest land and of the grazing land and between that of the cultivated and of the grazing lands (Table 3 ).

An increase in the level of SOM in the forest could have been the result of accumulation of plant residues in the upper few centimeters soil depth and their lower rate of decomposition and disturbances (Khresat et al., 2008 and Saikeh et al., 1998). Conversely, the decline in SOM contents in the cultivated land could be attributed to the effect of continuous cultivation that aggravates organic matter oxidation and insufficient inputs of organic 
substrates from the farming system due to residue removal and zero crop rotation. The presence of water erosion in the study area could also contribute for the lower amount of SOM. Thus, the amount of SOM could be rated as forest land $>$ grazing land $>$ cultivated land in the study area.

Considering the soil depth, higher amount of SOM was recorded on the top surface of all land use types (Table 3 ). This is apparent because it is attributed partly to the continuous accumulation of non-decayed and partially decomposed plant and animal residues on the surface soils. In general, forest clearing followed by conversion into agricultural fields in tropical ecosystems is known to bring about remarkable depletion of the SOM stock. Thus, population growth and low yields in the already cultivated lands have contributed much towards natural resource degradation that in turn led to serious soil erosion. Information gathered from the elderly local farmers also indicated that conversion of much of the natural forest into farmlands and settlement areas at the study site occurred due to rapid population growth and the resultant frequent land redistribution which took place since the mid-1970s. This general truth was already confirmed by different studies (Dawit Solomon et al., 2002 ;Wakene Negassa and Heluf Gebrekidan, 2003;Woldeamlak Bewket and Stroosnijder, 2003; Eyayu Molla et al., 2009) that reported lower levels of SOM under cultivated and grazing lands and with increasing soil depth elsewhere in Ethiopia.

Similar to SOM, the decline in TN by $46.77 \%$ in cultivated and by $17.42 \%$ in grazing lands from natural forest could be attributed to rapid mineralization of SOM following cultivation and grazing which disrupts soil aggregates and thereby increases aeration and microbial accessibility to SOM (Dawit Solomon et al., 2002). As the study area receives high rainfall, leaching loss of nitrate- $\mathrm{N}$ can also be a factor for the decline of $\mathrm{TN}$ in the cropped field. Thus, following the rating of TN by Landon (1991), the soils of the forest and the grazing lands of the study area qualify for medium and the cultivated land for low status of TN. This result agrees with studies

Table 3. Main effects of land use and soil depth on selected soil chemical properties

\begin{tabular}{cccccc}
\hline Treatment & $\mathrm{pH}\left(\mathrm{H}_{2} \mathrm{O}\right)$ & $\mathrm{SOM}(\%)$ & Total N $(\%)$ & $\mathrm{C}: \mathrm{N}$ ratio & Available P $\left(\mathrm{mg} \mathrm{kg}^{-1}\right)$ \\
\hline \multicolumn{7}{c}{ Land use } \\
\hline Forest land & $* * 5.86 \mathrm{a}$ & $* * 3.28 \mathrm{a}$ & $* * 0.31 \mathrm{a}$ & 6.14 & $* 4.41 \mathrm{a}$ \\
Grazing and & $* * 5.31 \mathrm{~b}$ & $* * 2.41 \mathrm{ab}$ & $* * 0.26 \mathrm{a}$ & 5.46 & $* 2.76 \mathrm{~b}$ \\
Cultivated land & $* * 5.20 \mathrm{~b}$ & $* * 2.12 \mathrm{~b}$ & $* * 0.17 \mathrm{~b}$ & 7.23 & $* 3.83 \mathrm{a}$ \\
\hline LSD $(0.05)$ & 0.335 & 0.759 & 0.061 & $\mathrm{NS}$ & 1.130 \\
\hline SEM $( \pm)$ & 0.106 & 0.241 & 0.019 & 1.040 & 0.359 \\
\hline $0-20$ & $* 5.32 \mathrm{~b}$ & $* * 3.05 \mathrm{a}$ & $* * 0.276 \mathrm{a}$ & 6.76 & 3.73 \\
\hline So-40 & $* 5.60 \mathrm{a}$ & $* * 2.15 \mathrm{~b}$ & $* * 0.211 \mathrm{~b}$ & 6.30 & 3.59 \\
\hline LSD $(0.05)$ & 0.273 & 0.620 & 0.051 & $\mathrm{NS}$ & $\mathrm{NS}$ \\
\hline SEM $( \pm)$ & 0.09 & 0.20 & 0.02 & 0.85 & 0.29 \\
\hline CV $(\%)$ & 4.77 & 22.66 & 19.74 & 29.36 & 23.95
\end{tabular}

Mean values within a column followed by the different letters are significantly different from each other at $* * \mathrm{P}<0.01$ and $* \mathrm{P}<0.05$. ( $\mathrm{NS}=$ Not significant; $\mathrm{SOM}=$ Soil Organic matter $)$ 
by Fantaw Yimer et.al. (2007) and Eyayu Molla et al.(2009) who found a decreasing trend of TN with increasing soil depth and land use type in the eastern and northwestern highlands of Ethiopia, respectively. Obviously, SOM and TN increase surface soil due to large amount of root biomass, external inputs like animal wastes and other plant debris that remain in the top surface soil as compared to the lower soil depths.

The $\mathrm{C}: \mathrm{N}$ ratios did not show significant differences between land use, depth and their interactions (Table 1 and 3). However, numerically the overall mean $\mathrm{C}: \mathrm{N}$ ratios among land use types were higher in cultivated land but lower in grazing land (Table 3). In general a $\mathrm{C}: \mathrm{N}$ ratio less than 10 may indicate the incorporation of low levels of organic matter in the soils of these land use types (Sakih et al, 1998). Coupled to this, aeration and increased temperature that enhance mineralization rates of organic carbon than organic nitrogen could probably be the causes for the lower level of $\mathrm{C}: \mathrm{N}$ ratio in these land use types (Dawit Solomon et al., 2002). This result agrees with studies by Abbasi et al. (2007) who found lower $\mathrm{C}: \mathrm{N}$ ratios in the soils of natural vegetation than of arable lands. It, however, disagrees with the results of Sakih et al. (1998) and Fantaw Yimer et al. (2007), who reported lower $\mathrm{C}: \mathrm{N}$ ratios for arable soils as compared to soils under forest land. Such discrepancies showed that the results obtained from a $\mathrm{C}: \mathrm{N}$ ratio may be considered less informative of the SOM quality than the $\mathrm{C}$ and $\mathrm{N}$ contents alone (Abbasi et al., 2007).

\section{Available phosphorus (AP)}

The amount of AP was significantly $(\mathrm{p}<0.05)$ affected by land use, whereas soil depth and its interaction with land use was insignificant $(p>$
0.05 ; Table 1). In the forest land it was significantly higher than in cultivated land, while it was statistically similar with grazing land (Table 3). An increase in AP content in the natural forest followed by grazing land could be ascribed to the relative higher organic matter content in these soils as AP was strongly associated with $\mathrm{SOM}\left(r^{2}\right.$ $=0.64, \mathrm{p}<0.01)$. This indicates that variations in AP among soils of different land uses were mostly a function of total SOM dynamics that was affected by land use changes (Eyayu Molla et al., 2009). It has been reported that the distribution and availability of AP in the soil is regulated by biochemical processes since most of the $\mathrm{P}$ available in plants is derived from the SOM (Dawit Solomon et al., 2002a). On the other hand, AP decreased by $3.75 \%$ with increasing soil depth. This is attributed to the increment in clay content with depth that might have caused phosphorus fixation and a decline in SOM with depth as evidenced by this study. This result is, therefore, in agreement with Ahmed Hussien (2002) who detected lower values of AP with increasing soil depth at Mount Chilalo, southeastern Ethiopia. In general, the amount of AP in the study area is small as per the ratings of Landon (1991) where he rated AP less than 5 mgkg${ }^{1}$ as low.

\section{Cation exchange capacity (CEC)}

CEC of the soils in the study area were significantly $(p<0.01)$ affected by land use, soil depth and their interaction effects (Table 1). Considering the main effects of land use, the highest $\left(23.27 \mathrm{cmol} \mathrm{kg}_{\mathrm{c}}^{-1}\right)$ and the lowest $(21.44$ $\mathrm{cmol}_{\mathrm{c}} \mathrm{kg}^{-1}$ ) values of CEC were detected under the forest and the cultivated lands, respectively (Table $4)$.

The CEC values in the cultivated land decreased mainly due to the reduction in SOM content. 
Basically, soil CEC is determined by the relative amounts and/or types of the two colloidal substances: humus and clay. SOM particularly plays an important role in the soil exchange processes because it provides more negatively charged surfaces than clay particles do. As a result this study showed a positive correlation between CEC and organic matter $\left(\mathrm{r}=0.52^{*}, \mathrm{p}<0.05\right)$. Similarly, CEC values were affected by increasing soil depth where it declined by $5.28 \%$. Such drop down in CEC value in the subsoil with the parallel decline of SOM content is expected under normal circumstances. Thus, from this result we infer that SOM has strong association and influences the distribution of CEC. The result is in agreement with the findings by Woldeamlak Bewket and Stroosnijder (2003) that showed a decline in CEC from $37.0 \mathrm{cmol}_{\mathrm{c}} \mathrm{kg}^{-1}$ in forest land to $14.0 \mathrm{cmol}_{\mathrm{c}} \mathrm{kg}^{-1}$ in cultivated land in the Chemoga watershed, Blue Nile basin, northwestern Ethiopia. Therefore, the change of forest to crop land and other land use type without proper management aggravates soil fertility reduction.

Percentage base saturation (PBS) was not significantly $(\mathrm{p}>0.05)$ affected by land use, soil depth and their interactions (Table 1). The highest $(89.73 \%)$ and the lowest $(72.65 \%)$ values of PBS were recorded under the forest and the cultivated lands, respectively. On the other hand, with soil depth the higher value was observed in the subsoil layer with insignificant difference (Table 4). In general, the trends on the distribution of PBS showed similarity with the distribution of CEC and exchangeable bases since factors that affect these soil attributes also affect the PBS.

Table 4. Main effects of land use and soil depth on exchangeable bases, cation exchange capacity (CEC) and percent base saturation (PBS).

\begin{tabular}{|c|c|c|c|c|c|c|}
\hline \multirow{2}{*}{$\begin{array}{l}\text { Land use/ } \\
\text { soil depth }\end{array}$} & \multicolumn{4}{|c|}{ Exchangeable base $\left(\mathrm{cmol} \mathrm{kg}^{-1}\right)$} & \multirow{2}{*}{$\begin{array}{l}C \quad \text { E } \\
\left(\mathrm{cmol}_{\mathrm{c}} \mathrm{kg}^{-1}\right)\end{array}$} & \multirow{2}{*}{$\begin{array}{cl}C & P \quad B \\
& (\%)\end{array}$} \\
\hline & $\mathrm{Ca}$ & $\mathrm{Mg}$ & $\mathrm{K}$ & $\mathrm{Na}$ & & \\
\hline \multicolumn{7}{|l|}{ Land use } \\
\hline Forest land & 15.78 & 3.67 & $\begin{array}{l}* * \\
1.23 \mathrm{a}\end{array}$ & $* 0.12 \mathrm{ab}$ & $* * 23.27 \mathrm{a}$ & 89.73 \\
\hline Grazing land & 12.29 & 3.23 & $* * 0.50 \mathrm{~b}$ & $* 0.14 \mathrm{a}$ & $* * 22.18 \mathrm{a}$ & 72.88 \\
\hline Cultivated land & 11.97 & 3.00 & $* * 0.46 \mathrm{~b}$ & $* 0.10 \mathrm{~b}$ & $* * 21.44 \mathrm{~b}$ & 72.65 \\
\hline $\operatorname{LSD}(0.05)$ & NS & NS & 0.237 & 0.036 & 1.029 & NS \\
\hline $\operatorname{SEM}( \pm)$ & 1.34 & 0.32 & 0.08 & 0.01 & 0.33 & 6.84 \\
\hline \multicolumn{7}{|l|}{ Soil depth $(\mathrm{cm})$} \\
\hline $0-20$ & 12.87 & 3.09 & 0.70 & $* 0.10 \mathrm{~b}$ & $* * 22.91 \mathrm{a}$ & 73.16 \\
\hline $20-40$ & 13.82 & 3.52 & 0.76 & $* 0.14 \mathrm{a}$ & $* * 21.70 \mathrm{~b}$ & 84.01 \\
\hline $\operatorname{LSD}(0.05)$ & NS & NS & NS & 0.029 & 0.840 & NS \\
\hline $\operatorname{SEM}( \pm)$ & 1.09 & 0.26 & 0.06 & 0.01 & 0.27 & 5.59 \\
\hline CV (\%) & 24.64 & 23.59 & 25.41 & 23.76 & 3.58 & 21.36 \\
\hline
\end{tabular}

Mean values within a column followed by the different letters are significantly different from each other at $* * \mathrm{P}<0.01$ and $* \mathrm{P}<0.05$. NS $=$ not significant. 


\section{Exchangeable bases (Ca, Mg, $\mathrm{K}$ and $\mathrm{Na}$ )}

Exchangeable $\mathrm{Ca}$ was dominant in the exchange sites of the soil colloidal materials. This was followed by $\mathrm{Mg}, \mathrm{K}$ and $\mathrm{Na}$ in that order. However, the contents of both exchangeable $\mathrm{Ca}$ and $\mathrm{Mg}$ were not significantly $(\mathrm{p}>0.05)$ affected by land use, soil depth and by the interaction of both factors (Table 1 and 4). Numerically lower values recorded in the cultivated land that might be related to the influence of intensity of cultivation and abundant crop residue harvest with little or no use of input as reported by He et al. (1999). However, the contents of both exchangeable $\mathrm{Ca}$ and $\mathrm{Mg}$ increased with soil depth. The increasing trend of exchangeable $\mathrm{Ca}$ and $\mathrm{Mg}$ with soil depth could be associated with an increase of clay particles in the sub surface than the surface soils as evidenced by the current study. The clay mineral components of soil have negatively charged sites on their surfaces which adsorb and hold positively charged ions (cations) by electrostatic force (Baker et al., 1997). Thus, the contents of exchangeable bases in the subsoil layers are governed by clay content.

On the other hand, exchangeable $\mathrm{K}$ content was significantly $(\mathrm{p}<0.01)$ affected only by land use type. Considering the main effects of land use, exchangeable $\mathrm{K}$ content was higher $\left(1.23 \mathrm{cmol} \mathrm{kg}_{\mathrm{c}}^{-1}\right)$ in the forest land and low $(0.46$ $\mathrm{cmol}_{\mathrm{c}} \mathrm{kg}^{-1)}$ in the cultivated land (Table 4). The higher content in the forest land could be related with its high $\mathrm{pH}$ value and was in agreement with the study reported by Mesfin Abebe (1996) that indicated the relationship between exchangeable $\mathrm{K}$ and tropical soils with higher $\mathrm{pH}$. The ranges of mean exchangeable $\mathrm{K}$ values observed in this study showed that it was above the critical levels $\left(0.38 \mathrm{cmol}_{\mathrm{c}} \mathrm{kg}^{-1}\right)$ for the production of most crop plants as indicated by Landon (1991). Generally, the lower exchangeable $\mathrm{K}$ contents in the cultivated and the grazing lands than in the forest land might be due to its continuous losses caused by intensive cultivation and grazing. Previous findings also considered these factors and the application of acid forming fertilizers as major factors affecting the distribution of $\mathrm{K}$ in soil systems mainly enhancing its depletion, especially in tropical soils (Baker et al., 1997). The content of exchangeable $\mathrm{Na}$ was significantly affected by land use and soil depth $(p \leq 0.05)$ while it was not significantly $(p>0.05)$ affected by land use and the interaction effect (Table 1). It was higher $\left(0.14 \mathrm{cmol}_{\mathrm{c}} \mathrm{kg}^{-1}\right)$ under the grazing land and lower $\left(0.10 \mathrm{cmol} \mathrm{kg}^{-1}\right)$ in the cultivated land (Table 4). Considering the two soil depths, the higher $\left(0.138 \mathrm{cmol}_{\mathrm{c}} \mathrm{kg}^{-1}\right)$ was recorded at the $0-20 \mathrm{~cm}$ depth.

This discrepancy in the values of exchangeable bases among land use types might be associated with an increase in acidity levels in the soils of cultivated and grazing lands in contrast to the soils of the natural forest that could have favored solubilization and removal of cations by leaching water. In general, deforestation, leaching, limited recycling of dung and crop residues in the soil, very low use of chemical fertilizers, continuous cropping with no or short fallow periods, overgrazing and soil erosion have contributed to the depletion of basic cations and CEC on the cultivated and grazing lands as compared to the adjacent forest land.

\section{CONCLUSION}

The empirical data obtained from this study revealed that differences in land use system and soil depth with respect to the measured 
parameters indicated changes in soil properties. The conversion of natural forest to cultivated and/or grazing lands caused the depletion of clay fractions, soil organic matter, available phosphorus and exchangeable $\mathrm{K}$ and $\mathrm{Na}$. Similar to land use type, soil attributes such as the sand and clay fractions, acidity, organic matter, total nitrogen and cation exchange capacity showed significant differences with soil depth. In many cases the cultivated land which was under continuous and intensive cultivation had the poorest soil quality. Therefore, it is clear from the results that soils of the Agedit watershed responded to changes in land use and soil depth through their features that determine soil fertility and productivity. These variations in soil quality between land use systems and soil depth are indicators of the risk to sustainable crop production in the study area. This could be related to frequent tillage practice, overgrazing, crop residue harvest, application of acid forming fertilizers and conversion of forested land to other land use types that caused poor nutrient availability in the soil and limited crop productivity. In order to improve the soil conditions and advance sustainable land use and agricultural productivity in the study area, this study recommends the use of more organic matter input, alternative cultivation practices, vegetation restoration, and improved crop and livestock varieties. It also suggests that educating and training local farmers in techniques of soil conservation for improved land and soil management can make a difference.

\section{ACKNOWLEDGEMENTS}

The authors are grateful for the financial support of Amhara National Regional State Bureau of Water Resources Development. We also acknowledge the
South Gondar Zone, Water Resource Development Department Management and staff members for their logistic support during field survey in the study area. Sincere thanks are extended to staff members of Gondar Soil Science Laboratory and to the National Soil Research Laboratory in Addis Ababa for their unreserved assistance during soil sample analysis.

\section{REFERENCES}

Abbasi, M.K., Zafar, M and Khan, S.R. (2007). Influence of different land-cover types on the changes of selected soil properties in the mountain region of Rawalakot Azad Jammu and Kashmir. Nutrient. Cycling in Agroecosystems 78: 97-110.

Adolfo-Campos, C., Klaudia, O.L., Jorge, E.B and Claudia, H.M. (2007). Exploring the effect of changes in land use on soil quality on the eastern slope of the Cotre de Perote volcano (Mexico). Forest Ecology and Management 248: 174-182.

Ahmed Hussien (2002). Assessment of spatial variability of some physicochemical properties of soils under different elevations and land use systems in the western slopes of Mount Chilalo, Arsi. MSc Thesis, Alemaya University, Ethiopia.

Amare Haileslassie, Priess, J., Veldkamp, E., Demil Teketay and Lesschen, J.P. (2005). Assessment of soil nutrient depletion and its spatial variability on smallholders' mixed farming systems in Ethiopia using partial versus full nutrient balances. Agriculture, Ecosystems and Environment 108:1-16. 
Baker, M.R., Nys, C and Picard, J.F. (1997). The effects of liming and gypsum application on a sessile oak (Quercus petraea) stand at Larcroix- Scaille (French Ardennes). I. Site characteristics, soil chemistry and aerial biomass. Plant and Soil 150: 99-108.

Betru Nedassa (2003). Soil and water conservation program in Amhara National Regional State. In: Proceeding of the Conference on the Natural Resource Degradation and Environmental Concerns in the Amhara National Regional State: Impact on Food Security, pp. 109-125. (Tilahun Amede ed.). The Ethiopian Society of Soil science (ESSS), Addis Ababa, Ethiopia.

\section{Blake, G.R. (1965). Bulk density. In: Methods of} Soil Analysis. Agronomy. Part I, No. 9, pp. 374-399 (Black,C.A. ed.), American Society of Agronomy, Madison, Wisconsin, USA.

Bremner, J.M and. Mulvaney, C.S. (1982). Nitrogen-total. In: Methods of soil analysis, Vol. 2. pp 595-624. (Page, A.L. Miller R.H and. Keeney, D.R. eds). American Society of Agronomy, Madison, Wisconsin, USA.

Celik, I. (2005). Land Use Effects on Organic Matter and Physical Properties of Soil in a Southern Mediterranean Highland of Turkey. Soil and Tillage 83: 270-277.

Chapman, H.D. (1965). Cation exchange capacity. In: Methods of soil analysis. Agronomy. 9: pp 891-901. (Black, C.A., Ensminger, L.E and Clark F.E., eds). American Society of Agronomy, Madison, Wisconsin, USA.

Chen, X.W and Li, B.L. (2003). Change in soil carbon and nutrient storage after human disturbance of a primary Korean pine forest in Northeast China. Forest Ecology and Management 186: 197-206.

Dawit Solomon, Fritzsche, F., Tekalign Mamo, Lehmann, J and Zech, W. (2002). Soil organic matter dynamics in the sub humid Ethiopian highlands: Evidence from natural ${ }^{13} \mathrm{C}$ abundance and particle size fractionation. Soil Science Society of American Journal 66: 969-978.

Dawit Solomon, Fritzsche, F., Tekalign Mamo, Lehmann, J and Zech, W. (2002a). Phosphorus forms and dynamics as influenced by land use changes in the sub-humid Ethiopian highlands. Geoderma 105: 21-98.

Day, P.R. (1965). Hydrometer method of particle size analysis. In: Methods of Soil Analysis. Agronomy. Part II, No. 9. pp. 562-563 (Black, C.A. ed.). American Society of Agronomy, Madison, Wisconsin, USA.

Eswaran, H., Lal, R. and Reich, P. F. (2001). Land degradation: An overview. In: Proceedings of the 2nd international conference on land degradation and desertification. $\mathrm{Pp} 20$ 35 (Bridges, E.M., Hannam, I.D., Oldeman, L.R., Pening de Vries, F.W.T., Scherr, S.J. and Sompatpanit S., eds.). Khon Kaen, Thailand. Oxford Press. New Delhi, India.

Eyasu Elias (2002). Farmers' perceptions of soil fertility change and management. SOS-Sahel and Institute for Sustainable Development. Addis Ababa, Ethiopia.

Eyayu Molla, Heluf Gebrekidan, Tekaliign Mamo and Mohammed Assen (2009). Effects of land use change on selected soil properties in the 
Tara Gedam Catchment and adjacent agroecosystems, north-west Ethiopia, Ethiopian Journal of Natural Resources 11(1): 35-62.

Eyayu Molla, Heluf Gebrekidan, Tekaliign Mamo and Mohammed Assen (2010). Patterns of land use/cover dynamics in the mountain landscape of Tara Gedam and adjacent agro-ecosystem, northwest Ethiopia. SINET: Ethiopian Journal of Science 33(2): 75-88.

Fantaw Yimer, Ledin, S. and Abdu Abdelkadir (2007). Changes in soil organic carbon and total nitrogen contents in three adjacent land use types in the Bale Mountains, south eastern highlands of Ethiopia. Forest Ecology and Management 242: 337-342.

FAO(Food and Agriculture Organization) (1984).

Assistance to land use planning, Ethiopia. Geomorphology and soils (1: 1, 000000 scalce). FAO/UNDP. Addis Ababa, Ethiopia.

He, Z.L., Alva, A.K., Calvert, D.V., Li Y.C and Banks, D.J (1999). Effects of nitrogen fertilization of grapefruit trees on soil acidification and nutrient availability in Riviera fine sand. Plant and Soil 206: 11-19.

Islam, K.R and Weil, R.R. (2000). Land use effects on soil quality in a tropical forest ecosystem of Bangladesh. Agriculture, Ecosystem and Environment 79: 9-16.

Khresat, S., Al-Bakri, J and Al-Tahhan, R. (2008). Impacts of land use/cover change on soil properties in the Mediterranean region of northwestern Jordan. Land Degradation and Development 19: 397-407.

Kumar, R., Rawat, K.S and Yadav, B. (2012). Vertical distribution of physico-chemical properties under different topo-sequence in soils of Jharkhand. Journal of Agricultural Physics 12 (1): 63-69.

Landon, J.R. (1991). Booker Tropical Soil Manual: a handbook for soil survey and agricultural land evaluation in the tropics and subtropics. Paperback edition Longman Science and Technology: Harlow.

Mesfin Abebe (1996). The challenges and future prospects of soil chemistry in Ethiopia. In: Proceedings of the 3rd Conference of the Ethiopian Society of Soil Science (ESSS). pp. 78-96. (Teshome Yizengaw, Eyasu Mekonnen and Mintesinot Behailu eds.). Ethiopian Science and Technology Commission. Addis Ababa, Ethiopia.

Mohr, P.A. (1971). The Geology of Ethiopia. Haile Sellassie I University Press. Addis Ababa, Ethiopia.

Mulugeta Lemenih and Fisseha Itanna. (2004). Soil carbon stock and turnovers in various vegetation types and arable lands along an elevation gradient in southern Ethiopia. Geoderma 123: 177-188.

Olsen, S.R.., Cole, C.W., Watanabe, F.S and. Dean, L.A. (1954). Estimation of available phosphorus in soils by extraction with sodium bicarbonate. U.S. Department of Agriculture, Circular 939. USDA.

Rao, K. S. and Pant, H., (2001). Land use dynamics and landscape change pattern in a typical micro watershed in the middle elevation zone of central Himalaya, India. Agriculture, Ecosystem and Environment 86: 113-123. 
Saikh, H., Varadachari, C and Ghosh, C. (1998). Changes in carbon, nitrogen, and phosphorus levels due to deforestation and cultivation: a case study in Simlipl National Park, India. Plant and Soil 198: 137-145.

SAS (Statistical Analysis System), 2002. SAS/ STAT user's guide. Proprietary software version 9.00. SAS Inst., Inc., Cary, NC.

Tekalign Tadesse (1991). Soil, plant, water, fertilizer, animal manure and compost analysis. Working Document No.13. ILCA, Addis Ababa.

UNDP (United Nations Development Programme) (2014). Ethiopia fact sheet :Agricultural Growth and Transformation. UNDP. http:// www.undp.org/content/dam/ethiopia/docs/ UNDP., (accessed on March, 2015)

Wakene Negassa and Heluf Gebrekidan (2003). Influence of land management on morphological, physical and chemical properties of some soils of Bako, Western Ethiopia. Agropedology 13(2): 1-9.

Walkley,A.andBlack, C.A.(1934).An examination of different methods for determining soil organic matter and the proposed modifications by the chromic acid titration method. Soil Science 37: 29-38.

Woldeamlak Bewket and Stroosnijder, L. (2003). Effects of agro-ecological land use succession on soil properties in the Chemoga watershed, Blue Nile Basin, Ethiopia. Geoderma 111: 8598. 